\title{
Proposing Geo-Products for Ly Son Geopark, Vietnam `
}

\author{
Hoang Thi Phuong Chi *, Ha Quang Hai and Nguyen Thi Que Nam \\ Faculty of Environment, University of Science, Vietnam National University, Hochiminh City 700000, \\ Vietnam; hqhai@hcmus.edu.vn (H.Q.H.); quenam93@gmail.com (N.T.Q.N.). \\ * Correspondence: htpchi@hcmus.edu.vn \\ + Presented at the 1st International Electronic Conference on Geosciences, 15-30 June 2018; Available online: \\ https://iecg_2018.sciforum.net/.
}

Published: 14 June 2018

\begin{abstract}
Ly Son district includes two off-shore volcanic islands: Ly Son Island (Re Isle) and Little Island (Bo Bai Isle), located in the eastern part of Quang Ngai Province, central Vietnam. It covers approximately $9.97 \mathrm{~km}^{2}$ of land. Ly Son and the surrounding area will be applying to become a UNESCO Global Geopark. The island district is a product of volcanic activity that creates a wide variety of geomorphology forms: modern marine deposition, marine sediment, basalt flow and volcanic eruptions, and other geo-features. As a result of the geosite inventory, together with the assessment of scientific value and additional values (ecology, culture/history, economics, aesthetics), this study was conducted to propose a wide range of geo-products for Ly Son Geopark. The suggested products include: tourist center; scientific interpretation services such as introduction, providing explanations of scientific values of Ly Son Geopark; geo-trails, geo-roads, and geo-adventures; as well as local products. Geo-products will definitely contribute to support local economic development, appealing to tourists and effectively enhancing Earth Sciences education and conservation.
\end{abstract}

Keywords: Ly Son Geopark; geosites; geo-products

\section{Introduction}

The term geo-tourism, defined more than 20 years ago, is a part of sustainable tourism, which plays an important role in the development and preservation of geological heritage. Today, geotourism is also considered a science of modern geology and is a subject taught in universities around the world. Geo-tourism is a new niche market [1]. Therefore, geo-tourism endeavors have had to introduce their attractions and targets to visitors. Such endeavors should set up strategies to attract more tourists to geoheritage sites. Geosites, along with their geo-products, are very important providers of pedagogical tools and educational activities for tourists. According to UNESCO Global Geoparks Network Guidelines, some geo-products such as museums, interpretive and educational centers, trails, guided tours, popular literature, and maps can provide supports, tools, and activities to communicate geoscientific knowledge and environmental and cultural concepts to the public [2].

Ly Son district consists of two off-shore islands: Ly Son Island (Re Isle) and Little Island (Bo Bai Isle), located in the eastern part of Quang Ngai Province. This small district is 15 nautical miles off the south-central coast of Vietnam, covering approximately $9.97 \mathrm{~km}^{2}$ of land. The island district is a product of volcanic activity that creates a wide variety of incredible landscapes. Ly Son geomorphology is based on basaltic characteristics: the erupting volcanoes on the island released prominent craters, while basaltic flow formed a low covering at the foot of the volcanoes. Marine sediments are mainly coral sandstone, and the coral reefs distributed around the island are often flooded with tides. Significant destruction causes by the waves crashing repeatedly into the volcanic slopes and basaltic cover forms has resulted in many splendid landscapes and historical sites along 
the island, such as sea-cliffs, caves, rocky coasts, and stone towers [3]. An inventory has identified 18 geosites on Re Isle and nine geosites on Bo Bai Isle in the following four categories: geomorphology, complexity (geology and geomorphology), hydrology, and landscape-geomorphology [4]. These geosites were evaluated for scientific and additional values based on prior studies and reports by geological scientists, such as field surveys that identified the morphology, structure, boundaries, stratigraphic features, and geomorphology at each site. The most attractive geo-spot of this island is the volcanic sea-cliff from Hang Cau to Chua Hang (the stunning caves on Ly Son Island), from which the volcano structures as well as the stratigraphic relationships between the volcanic rock and coral sandstone (calcarenite) layers are visible. This potential global geosite could be qualitatively evaluated with the criteria of rarity and uniqueness in Vietnam [4].

\section{Methods}

In this study, potential geo-products were proposed according to fieldwork and, after that, the basic classification and assessment of scientific and additional values for geosites. After identifying all values that confirmed the development of geo-products, the research proposed specific types of products and services based on the classification systems of Reynard (2008) [6] and Diana Dryglas and Krzysztof Miśkiewicz (2014) [5]

Frey et al. (2006) emphasized that geo-tourism products should involve pedagogical approaches in environmental education, geological multidisciplinary guidance and research, economic issues, and sustainable development [7]. The core products, which are abiotic components of nature, should be presented to show a wide range of geo-information in the research area [5]. Therefore, the most basic category (objects) would be developed first.

Table 1. Proposed geo-products in Ly Son Geopark.

\begin{tabular}{|c|c|c|}
\hline Level & Type & Geo-Products \\
\hline \multirow{4}{*}{ Basic } & Objects & $\begin{array}{ll}\text { - } & \text { Printed material: geo-tourist/geo-map; brochure; geological guides } \\
\text { - } & \text { Geo-interpretative panels system } \\
\text { - } & \text { Promotional geo-souvenirs, local foods with logo or geosite images of Ly Son } \\
\text { Geopark. }\end{array}$ \\
\hline & Entity & $\begin{array}{ll}- & \text { Geo-center } \\
- & \text { Geo-museum } \\
\end{array}$ \\
\hline & Event & $\begin{array}{ll}\text { - } & \text { Local festival exhibitions to introduce Ly Son Geopark } \\
\text { - } & \text { Geo-conferences; geo-presentations } \\
\end{array}$ \\
\hline & Service & - $\quad$ Guided geo-services \\
\hline \multirow{3}{*}{ Complex } & $\begin{array}{l}\text { Tourism } \\
\text { package }\end{array}$ & $\begin{array}{ll}- & \text { Geo-tour package } \\
\text { - } & \text { Geo-adventure for students } \\
\end{array}$ \\
\hline & Geo-trail & - $\quad$ Geo-tourist trail \\
\hline & Place & - UNESCO Geopark \\
\hline
\end{tabular}

\section{Result and Discussion}

In this section, the proposed geo-products to promote tourism growth are detailed below: tourist geo-center, interpretation system of scientific and additional values, and geo-trail. In addition, the development of local products for geo-tourism is suggested.

\subsection{Geo-Center}

Position: The geo-center should be located in the An Hai communal house and the monument of "Hoang Sa Bac Hai Fleet", a symbolic assertion of Vietnam's sovereignty over the Hoang Sa (Paracel) archipelago.

Name: Ly Son Geo-Center.

It consists of:

(1) Hoang Sa-Bac Hai Fleet Exhibition Hall 
(2) Geo-tourism center: providing information on the Geopark, such as its geosites, geological services, and geo-tour services

(3) Geo-museum featuring two rooms:

(3a) the Ly Son Room displaying geological features

(3b) a gallery featuring other art products

(4) Geo-souvenir area: introducing local products such as geo-handicrafts, geo-ornaments, local foods.

\subsection{The Geo-Interpretation System}

\subsubsection{Logo for Ly Son Geopark}

Designing a logo will accelerate the promotion of Ly Son Geopark to visitors. Products with the logo such as t-shirts, cups, hats, badges, and other local products that are sold to visitors as souvenirs will also serve to promote the image of Ly Son Geopark.

The proposed logo is based on the shape of Thoi Loi volcano on Re Isle. On the way to the island, the volcano looks like a ship riding the waves to the east. This very simple yet significant image is suggested for the logo of Ly Son Geopark (Figure 1).

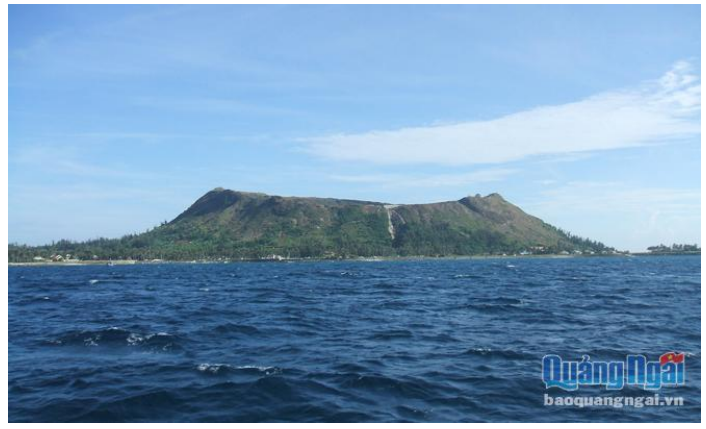

(a)

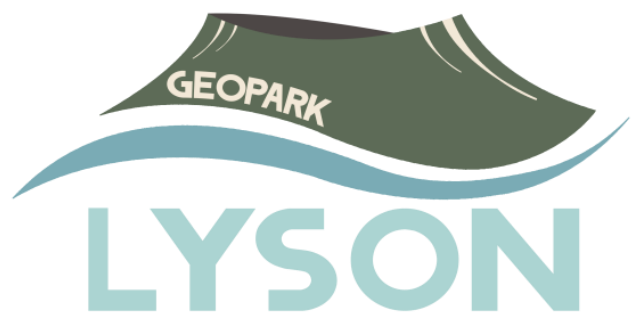

(b)

Figure 1. (a) Thoi Loi volcano on Ly Son island [8]. (b) Ly Son Geopark logo.

\subsubsection{Geo-Interpretation System}

The geo-interpretation system in Ly Son Geopark would consist of panels and several printed products, including geo-touristic maps, brochures, and geological guides.

The geo-interpretation panels would provide precise scientific information and convey the additional values of the sites. They should be located at every geosite, so that tourists can be informed without instruction. Their contents would conclude: (1) the geosite location on the map; (2) a description of the geosite; (3) scientific and additional values (Table 2); (4) images for illustration.

Table 2. Some information included in the geo-interpretation panels.

\begin{tabular}{|c|c|}
\hline \multirow{2}{*}{ Location } & Content \\
\hline & $\begin{array}{l}\text { Scientific Information } \\
\end{array}$ \\
\hline $\begin{array}{c}\text { Entrance of } \\
\text { Ly Son } \\
\text { Geopark }\end{array}$ & $\begin{array}{l}\text { Ly Son Island is a product of volcanic activity with a very young age (Holocene age). The } \\
\text { island holds an important strategic position in the East Sea of Vietnam and contains diversified } \\
\text { tourism potential and valuable geo-heritage sites on Hoang Sa (Paracel) Archipelago. This } \\
\text { geopark includes } 18 \text { geosites on Re Isle and nine geosites on Bo Bai Isle, which are classified } \\
\text { into four categories: geomorphology - stratigraphy geosites, geomorphology geosites, } \\
\text { hydrology geosites, and landscape-geomorphology geosites. Significant destruction caused } \\
\text { by the waves crashing repeatedly into the volcanic slopes and basaltic cover forms has resulted } \\
\text { in the creation of many splendid landscapes and historical sites along the island, such as sea } \\
\text { walls, caves, rocky coasts, and stone towers. Some popular attractions in Ly Son are: Hang } \\
\text { Cau and Chua Hang (stunning sea caves), Thoi Loi volcano, To Vo Gate (natural stone arches) } \\
\text { on Re Isle, and Fairy Beach on Bo Bai Isle. }\end{array}$ \\
\hline
\end{tabular}




\subsection{Geo-Trail}

A geo-trail links geologically significant sites and creates an educational journey for people to follow. Typically, trail information is contained in a field guide brochure and includes an introduction to the geological history, maps and diagrams, details and photographs, self-guided tours, and safety guidance. The provided information is usually scientific in nature [9].

One of the important goals of the geopark is to preserve the geosites' integrity. In addition, as the geopark is made up of two isles with a small surface area, this study proposed geo-trails accessible by two modes of transport: traveling by road (cycling and walking are encouraged) and traveling by waterway (by ship). The suggested geo-trails are listed in Table 3 and illustrated in the geo-trail map in Figure 2. Moreover, some images of the geosites are provided in Figure 3.

Table 3. Proposed geo-trail on Re Isle.

\begin{tabular}{|c|c|c|c|c|c|}
\hline No. & Geo-Trail Name & Distance & $\begin{array}{l}\text { Means of } \\
\text { Transport }\end{array}$ & $\begin{array}{c}\text { Total } \\
\text { Traveling } \\
\text { Time } \\
\end{array}$ & Description Route \\
\hline 1 & $\begin{array}{l}\text { Following the lava } \\
\text { flow (from Hang Cau } \\
\text { to To Vo Natural Gate) }\end{array}$ & $9.5 \mathrm{~km}$ & Cycling & $4 \mathrm{~h}$ & $\begin{array}{l}\text { Sightseeing and learning about the } \\
\text { formation of Hang Cau sea-cliff, sea } \\
\text { caves, Chua Hang (Pagoda in cave), } \\
\text { Duc Pagoda, Gieng Tien Volcano, and } \\
\text { To Vo Natural Gate. }\end{array}$ \\
\hline 2 & $\begin{array}{l}\text { The route to a two- } \\
\text { tiered volcano (from } \\
\text { Ly Son Flagpole to } \\
\text { Thoi Loi Reservoir on } \\
\text { the crater) }\end{array}$ & $1.3 \mathrm{~km}$ & Walking & $4 \mathrm{~h}$ & $\begin{array}{l}\text { - Observing a two-tiered volcanic } \\
\text { structure, stone towers, and stone } \\
\text { mushrooms. } \\
\text { - Enjoying the scenery of Ly Son from } \\
\text { above. }\end{array}$ \\
\hline 3 & $\begin{array}{l}\text { Following the Sun } \\
\text { (from Mu Cu Islet to } \\
\text { To Vo Natural Gate) }\end{array}$ & $8.8 \mathrm{~km}$ & Cycling & $12 \mathrm{~h}$ & $\begin{array}{l}\text { - Enjoying the dawn at Mu Cu Islet } \\
\text { - Visiting An Hai Temple, Hoang Sa } \\
\text { Bac Hai Exhibition Hall (Geo-Center), } \\
\text { King Well, Am Linh Tu Temple, and } \\
\text { Hoang Sa Soldier Graves } \\
\text { - Joining in the planting, caring, and } \\
\text { harvesting of garlic with local people }\end{array}$ \\
\hline 4 & $\begin{array}{c}\text { Hang Cau-Chua } \\
\text { Hang coastal geo-trail }\end{array}$ & $1.2 \mathrm{~km}$ & Walking & $12 \mathrm{~h}$ & $\begin{array}{l}\text { - Walking along to the modern sea- } \\
\text { cliff from Chua Hang (Pagoda in } \\
\text { cave) to Hang Cau } \\
\text { - Night camping on Hang Cau beach. }\end{array}$ \\
\hline 5 & $\begin{array}{l}\text { Gieng Tien geo-trail } \\
\text { (from Duc Pagoda to } \\
\text { To Vo Natural Gate) }\end{array}$ & $1 \mathrm{~km}$ & Walking & $3 \mathrm{~h}$ & $\begin{array}{l}\text { - Visiting Duc Pagoda } \\
\text { - Climbing up the Gieng Tien crater } \\
\text { - Watching the sunset at To Vo } \\
\text { Natural Gate }\end{array}$ \\
\hline 6 & $\begin{array}{c}\text { Duc Pagoda-Chua } \\
\text { Hang (Pagoda in cave) }\end{array}$ & $2.8 \mathrm{~km}$ & Boating & $3 \mathrm{~h}$ & $\begin{array}{l}\text { - Enjoying the sights of Gieng Tien } \\
\text { Volcano, Dong Ho Beach, and Hang } \\
\text { Pagoda from the sea. }\end{array}$ \\
\hline 7 & $\begin{array}{c}\text { Hang Pagoda }-\mathrm{Mu} \mathrm{Cu} \\
\text { Islet }\end{array}$ & $3.4 \mathrm{~km}$ & Boating & $4 \mathrm{~h}$ & $\begin{array}{l}\text { - Observing the two-tiered volcanic } \\
\text { landscape. } \\
\text { - Watching An Hai lighthouse and } \\
\text { Mu Cu fishing port from the sea. }\end{array}$ \\
\hline
\end{tabular}




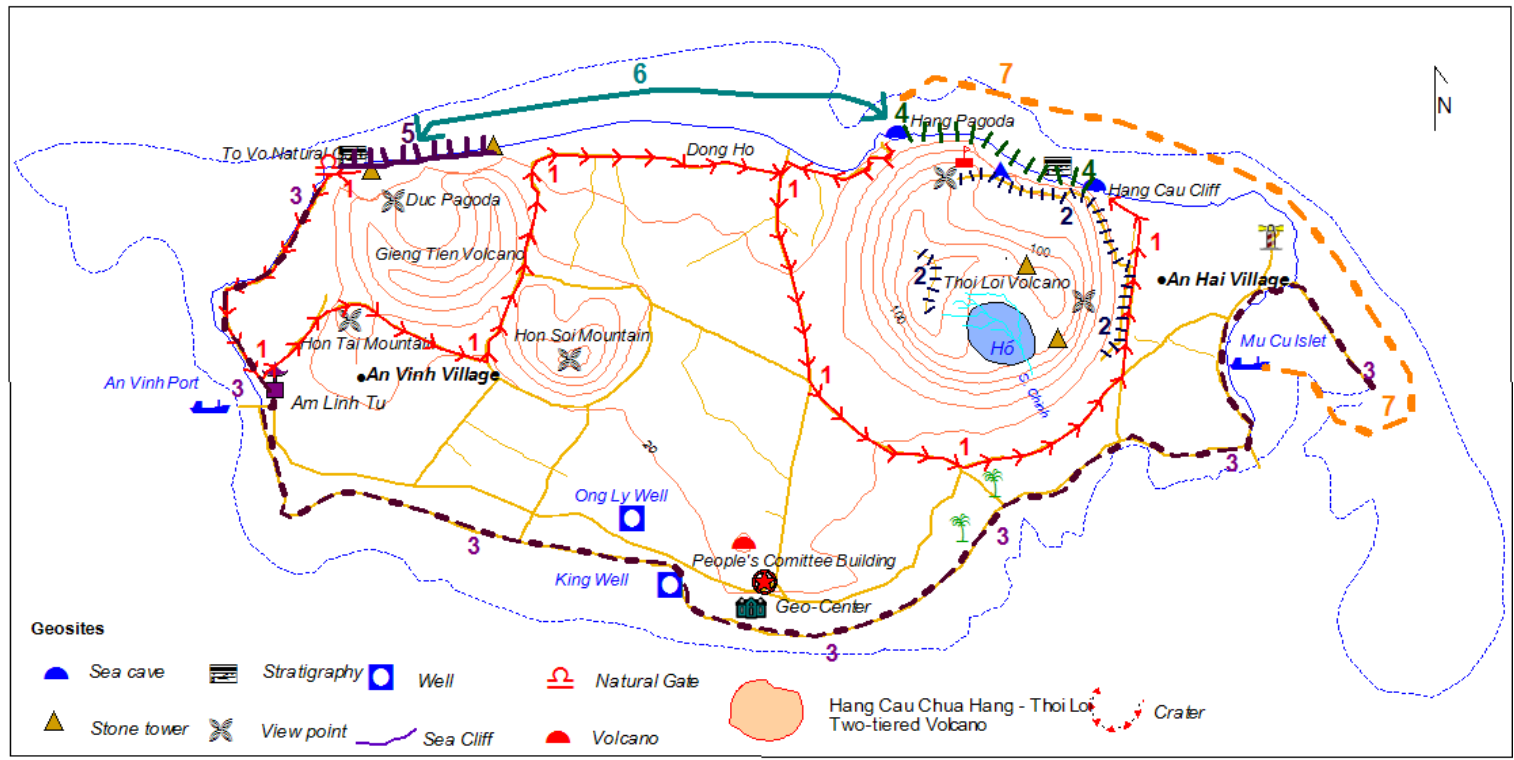

Figure 2. Route of the geo-trails on Ly Son Island (Re Isle) Map.

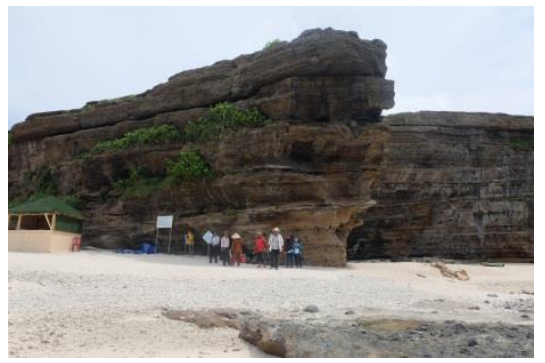

Hang Cau Cliff

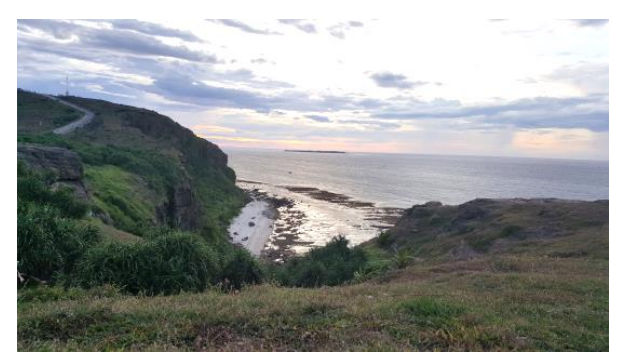

The most impressive geo-trail in Ly Son Geopark

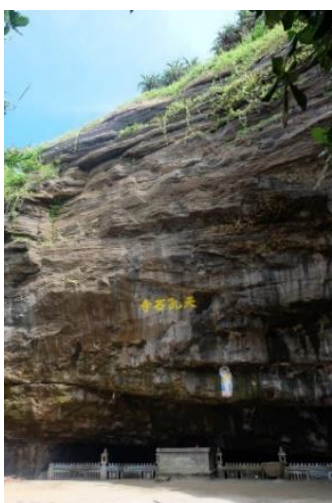

Chua Hang Cave

Figure 3. Illustrated pictures for Geo-trail 4.

\subsection{Local Products for Geo-Tourism}

\subsubsection{Cuisine}

Local cuisine is one of the important geo-products with high additional value that contributes to the brand of Ly Son Geopark. Ly Son is the kingdom of garlic, which has a strong-smelling and distinctive delicious taste, to which other products of this kind cannot compare. In addition, fresh seafood such as crab, oyster, fish, sea-urchin, and seaweed are also attractive. For culinary enthusiasts, Ly Son is an ideal place to enjoy fresh seafood combined with spices in traditional recipes. Developing cuisine is an irreplaceable geo-product for Ly Son Geopark.

Moreover, activities such as planting, caring, and harvesting garlic; picking seaweed; fishing; and other activities with local people also offer new experiences and attractions to tourists.

\subsubsection{Cultural Heritage and Local Special Festivals}

The cultural and historical values of Ly Son Geopark are highly appreciated by scientists.

Ly Son is a lively museum of legends, stories, folk songs, spiritual festivals, etc., especially the Feast and Commemoration Festival for Hoang Sa Soldiers. The cultural and historical value of this area should be developed into plays, cultural shows, and other kinds of art to enrich the available tourism products. 


\section{Conclusions}

Geo-tourism creates opportunities for the development of the local economy and the conservation of geo-heritage sites. Therefore, the creation of more geo-products is a strategy to identify a particular geosite as a new tourist attraction. This study proposed basic to complex geoproducts for Ly Son Geopark, such as a geo-center, an interpretation System, geo-trails, and other potential local products. Ly Son Geopark has been researched and is proposed to become a Global Geopark. Thus, geo-tourism development, especially geo-products, will definitely contribute to support local economic development, appealing to tourists as well as effectively enhancing Earth Sciences education and conservation.

\section{References}

1. Farsani, N.T.; Coelho, C.; Costa, C. Geoparks and Geotourism: New Approaches to Sustainability for the 21st Century; Universal-Publishers: Irvine, CA, USA, 2011.

2. UNESCO (2010). Guidelines and Criteria for National Geoparks Seeking UNESCO's Assistance to Join the Global Geoparks Network (GGN). Available online: http://www.unesco.org/new/fileadmin/multimedia/HQ/ SC/pdf/sc_geoparcs_2010guidelines.pdf (accessed on 9 May 2018).

3. Hai, H.Q.; Tu, T.T.; Viet, P.H.; Thu, T.T.K. Volcanic Island Ly Son Tourism. Geo-Environment Information Gateway. 2015. Available online: https://diamoitruong.com/2015/10/20/du-lich-dao-nui-lua-ly-son-cu-laore-cu-lao-bo-bai/ (accessed on 9 May 2018). (In Vietnamese)

4. Hai, H.Q.; Nhi, N.T.H. Preliminary Inventory and Valorization Geosites in Ly Son Islands, Quang Ngai Province. Geo-Environment Information Gateway. 2018. Available online: https://diamoitruong.com/2018/03/18/kiem-ke-phan-loai-va-danh-gia-so-bo-geosite-dao-ly-son-tinhquang-ngai/ (accessed on 9 May 2018). (In Vietnamese)

5. Dryglas, D.; Krzysztof, M. Construction of the geotourism product structure on the example of Poland. In Proceedings of the 14th International Multidisciplinary Scientific Geoconference SGEM 2014, Albena, Bulgaria, 17-26 June 2014.

6. Emmanuel, R. Scientific research and tourist promotion of geomorphological heritage. Geogr. Fis. E Dinamm. 2018, 31, 225-230.

7. Frey, M.; Schäefer, K.; Büchel, G. Geoparks-A regional, European and global policy. In Geotourism; Dowling, R., Newsome, D., Eds.; Elsevier, Ltd.: Oxford, UK, 2006; pp. 96-117.

8. Thoi Loi Volcano-Stunning Landscape. Quang Ngai Newspaper. Available online: http://baoquangngai.vn/channel/2047/201707/nui-thoi-loi-thang-canh-thien-nhien-doc-dao-2826062/ (accessed on 9 May 2018). (In Vietnamese)

9. Campbell, B.; Jones, L. The Living Earth. 2013. Available online: http://www.cradlecoast.com (accessed on 9 May 2018).

(C) 2018 by the authors. Licensee MDPI, Basel, Switzerland. This article is an open access article distributed under the terms and conditions of the Creative Commons Attribution (CC BY) license (http://creativecommons.org/licenses/by/4.0/). 